\title{
24. CHEMISTRY OF THE MASSIVE SULFIDE DEPOSIT CORED AT SITE $471^{1}$
}

\author{
Joseph D. Devine and Margaret Leinen, Graduate School of Oceanography, \\ University of Rhode Island, Kingston, R.I.
}

\section{INTRODUCTION}

We report here chemical analyses of sulfide and other minerals occurring in the massive sulfide deposit cored at Site 471 . Details of the mineralogy and inferred paragenesis of the deposit will be reported elsewhere.

The sulfide deposit at Site 471 occurs between overlying pelagic sediment and underlying basalt. The deposit is vertically zoned and consists, from top to bottom, of the following mineral assemblages: (1) pyrite, chalcopyrite, and $\mathrm{Zn}$-sulfide in chert and calcite gangue $(\sim 35 \mathrm{~cm}$ thick); (2) a 5-cm-thick metalliferous sediment layer described in detail by Leinen (this volume); and (3) a 4-cm-thick chert layer (Table 1).

The overlying sediment is a calcareous silty claystone that contains middle Miocene coccoliths (Bukry, this volume).

The underlying basalt has been extensively chloritized and veined with calcite. In places feldspars are albitized, and calcite occurs as pseudomorphs after olivine. Relict textures suggest that the basalt grades into diabase and gabbro with increasing depth. Neither stockwork nor disseminated sulfides was observed in the altered rocks.

\section{METHODS}

Analyses were obtained using the JEOL JXA-50A electron microprobe in service at the University of Rhode Island Graduate School of Oceanography. The sulfide mineral standards we used were supplied by G. K. Czamanske and L. Calk of USGS, Menlo Park. We employed glass and mineral standards for analyses of silicates and other minerals.

Operating conditions for sulfide analyses were: $25 \mathrm{kV}$ accelerating voltage; $2.5 \times 10^{-8}$ amp beam current; 1 to $10 \mu \mathrm{m}$ beam diameter. Sulfide standards were used for the analysis of $\mathrm{Fe}, \mathrm{Ni}, \mathrm{Co}$, and $\mathrm{S}$, whereas metal standards were used for $\mathrm{Cu}$ and $\mathrm{Mo}$ and a glass standard for $\mathrm{Zn}$. MAGIC IV atomic number, absorption, and fluorescence (ZAF) corrections were applied automatically using a slaved PDP-11 minicomputer (Finger and Hadidiacos, 1972).

Silicate and other nonsulfide analyses were obtained under the following operating conditions: $15 \mathrm{kV}$ accelerating voltage; $1.25 \times 10^{-8}$ amp beam current; 1 to $10 \mu \mathrm{m}$ beam diameter. Alpha ZAF corrections (Bence and Albee, 1968) were applied automatically.

\section{RESULTS}

Table 2 shows the average composition of the three sulfide minerals and the metalliferous sediment that occur in the deposit (see Plates 1 and 2). Each of the sulfides contains small amounts of Mo, but $\mathrm{Ni}$ is negligible and Co was below the detection limit $(\sim 100 \mathrm{ppm})$. Some oxidation of sulfides at the top of the massive sulfide portion of the deposit has occurred (Plate 2, Fig. 1).

\footnotetext{
${ }^{1}$ Initial Reports of the Deep Sea Drilling Project, Volume 63.
}

Table 1. Site 471 massive sulfide deposit sample identification.

\begin{tabular}{|c|c|}
\hline $\begin{array}{l}\text { Sample } \\
\text { (interval in } \mathrm{cm} \text { ) }\end{array}$ & Description \\
\hline $471-79-1,49-54 \mathrm{~cm}$ & Massive sulfide in chert and calcite gangue. \\
\hline $471-79-1,58-62 \mathrm{~cm}$ & Massive sulfide in chert and calcite gangue. \\
\hline $471-79-1,74-77 \mathrm{~cm}$ & Massive sulfide in chert and calcite gangue. \\
\hline $471-79-1,82-85 \mathrm{~cm}$ & Massive sulfide in chert and calcite gangue. \\
\hline $471-79-1,87-92 \mathrm{~cm}$ & $\begin{array}{l}\text { Metalliferous sediment; } 2.5-\mathrm{cm} \text {-thick red } \\
\text { layer overlying } 2.5-\mathrm{cm} \text {-thick green layer. }\end{array}$ \\
\hline $471-79-1,93-97 \mathrm{~cm}$ & Chert clast containing silicified fossils. \\
\hline $471-79-1,97-101 \mathrm{~cm}$ & Chloritized basalt. \\
\hline $471-79-2,0-5 \mathrm{~cm}$ & $\begin{array}{l}\text { Chloritized diabase ( } .5 \text { meter below } \\
\text { sediment/basalt interface). }\end{array}$ \\
\hline $471-88-1,67-74 \mathrm{~cm}$ & $\begin{array}{l}\text { Chloritized gabbro ( } 72 \text { meters below } \\
\text { sediment/basalt interface). }\end{array}$ \\
\hline
\end{tabular}

Table 2. Compositions of sulfides and metalliferous sediment (wt.\%).

\begin{tabular}{lcccc}
\hline & Pyrite & Chalcopyrite & Zn-sulfide & $\begin{array}{c}\text { Metalliferous } \\
\text { Sediment }^{\mathrm{a}}\end{array}$ \\
\hline $\mathrm{Fe}$ & $45.59(130)^{\mathrm{b}}$ & $29.61(115)$ & $7.59(319)$ & 15.01 \\
$\mathrm{Cu}$ & $0.42(93)$ & $34.10(152)$ & $1.26(105)$ & 0.0118 \\
$\mathrm{Zn}$ & $0.04(4)$ & $0.09(4)$ & $60.66(383)$ & 0.0098 \\
$\mathrm{Mo}$ & $0.28(6)$ & $0.14(7)$ & $0.20(5)$ & - \\
$\mathrm{Co}$ & 0.00 & 0.00 & 0.00 & 0.0052 \\
$\mathrm{Ni}$ & $0.01(2)$ & 0.00 & trace & 0.0269 \\
$\mathrm{Mn}$ & $0.06(8)$ & $0.01(1)$ & $0.01(6)$ & 0.62 \\
$\mathrm{Ca}$ & 0.00 & $0.01(1)$ & $0.04(1)$ & 0.88 \\
$\mathrm{Mg}$ & $0.07(5)$ & $0.46(6)$ & $0.94(10)$ & 4.75 \\
$\mathrm{Si}$ & - & - & - & 19.61 \\
$\mathrm{Al}$ & - & - & - & 8.03 \\
$\mathrm{~S}$ & $53.01(284)$ & $34.68(111)$ & $33.75(143)$ & - \\
Total & $99.47(329)$ & $99.10(322)$ & $104.56(168)$ & - \\
No. Anals. & 10 & 7 & 9 & - \\
\hline
\end{tabular}

${ }^{\mathrm{a}}$ From Leinen, this volume.

b Parenthesized figures represent the estimated standard deviation (esd) in terms of least units cited for the value to their immediate left, thus $\mathbf{4 5 . 5 9}$ (130) indicates an esd of $1.30 \mathrm{wt} . \%$.

Pyrite is the only polymorph of $\mathrm{FeS}_{2}$ indentified by us using X-ray diffractograms of polished thin sections. Some sulfides, however, are similar in appearance (Plate 3, Fig. 1) to spherulitic marcasite clusters found at the " $21^{\circ} \mathrm{N}$ " area (Hekinian et al., 1980). If these grains were once marcasite, they have subsequently inverted to pyrite.

The $\mathrm{Zn}$-sulfide has tentatively been identified as sphalerite, but we have not been able to confirm this identification using X-ray diffractograms of polished thin sections, because the $\mathrm{Zn}$-sulfide is not very abundant. The $\mathrm{Zn}$-sulfide has appreciable and variable $\mathrm{Fe}$ content (up to $11.99 \mathrm{wt} . \%$ ). The consistently high totals of the $\mathrm{Zn}$-sulfide analyses may be related to a systematic 
error in the $\mathrm{Zn}$ determinations because of matrix effects and large differences in the concentration of $\mathrm{Zn}$ between the synthetic glass standard $(0.632 \mathrm{wt} . \% \mathrm{Zn})$ and the sulfide unknowns ( $>50 \mathrm{wt} . \% \mathrm{Zn})$.

Table 3 contains analyses of chert from the deposit. Analyses in this table and the tables that follow are listed in order of increasing depth in the section. Chert occurs mainly as spherulitic epitaxial overgrowths on sulfide grain surfaces and as void fillings in the massive sulfide portion of the deposit (Plate 3, Fig. 2). The chert layer underlying the metalliferous sediment layer and some chert clasts in the massive sulfide region contain remnants of silicified fossils that were probably coccoliths (Plate 4, Fig. 1). Cherts in the deposit are relatively low in water content but otherwise are not unique.

Table 4 contains analyses of calcite. Calcite gangue appears at a later stage than chert gangue in the sequence of deposition, also filling in voids and fractures (Plate 4, Fig. 2). The manganese content of calcite

Table 3. Chert compositions (wt. \%).

\begin{tabular}{llll}
\hline & $\begin{array}{c}\text { Sample } \\
471-79-1, \\
49-54 \mathrm{~cm}\end{array}$ & $\begin{array}{c}\text { Sample } \\
471-79-1, \\
58-62 \mathrm{~cm}\end{array}$ & $\begin{array}{c}\text { Sample } \\
471-79-1, \\
93-97 \mathrm{~cm}\end{array}$ \\
\hline $\mathrm{SiO}_{2}$ & $96.34(68)^{\mathrm{a}}$ & $93.99(24)$ & $94.20(12)$ \\
$\mathrm{Al}_{2} \mathrm{O}_{3}$ & $0.28(7)$ & $0.74(37)$ & $0.63(40)$ \\
$\mathrm{TiO}_{2}$ & 0.00 & 0.00 & 0.00 \\
$\mathrm{FeO}^{* \mathrm{~b}}$ & 0.00 & $0.12(16)$ & 0.00 \\
$\mathrm{MgO}$ & 0.00 & $0.07(9)$ & 0.00 \\
$\mathrm{CaO}$ & trace & 0.00 & $0.01(1)$ \\
$\mathrm{Na} 2 \mathrm{O}$ & $0.03(2)$ & $0.31(34)$ & $0.06(4)$ \\
$\mathrm{K} 2 \mathrm{O}$ & trace & $0.05(0)$ & $0.09(11)$ \\
$\mathrm{MnO}$ & 0.01 & $0.02(2)$ & $0.02(3)$ \\
$\mathrm{Total}$ & $96.68(71)$ & $95.29(86)$ & $94.99(65)$ \\
No. Anals. & 8 & 2 & 2 \\
\hline
\end{tabular}

a Parenthesized figures represent the estimated standard deviation (esd) in terms of least units cited for the value to their immediate left, thus $96.34(68)$ indicates an esd of $0.68 \mathrm{wt} . \%$.

${ }^{b} \mathrm{FeO}^{*}=$ all iron calculated as $\mathrm{FeO}$. varies systematically, reaching a maximum at the top of the massive sulfide portion of the deposit. The iron content of the calcite passes through a maximum in carbonates that occur just above the metalliferous sediment layer.

Table 5 shows analyses of chlorites and a biotitephlogopite occurring in the altered basalt, diabase, and gabbro. The $\mathrm{Al}_{2} \mathrm{O}_{3}, \mathrm{FeO}^{*}$, and $\mathrm{MgO}$ contents of chlorites in Site 471 rocks are more variable from sample to sample than are those of chlorites from the Mid-Atlantic Ridge described by Humphris and Thompson (1978). The biotite-phlogopite occurs in the gabbro of Core 88 (72 meters below the sediment/basalt interface) and could be either a remnant intercumulus mineral or a metamorphic mineral.

Table 6 contains analyses of other minerals occurring in the massive sulfide deposit and the altered igneous rocks. Column 1 shows the composition of dolomite, which occurs as small $(\sim 40 \mu \mathrm{m})$ rhombs in apparently recrystallized calcite gangue (Plate 5, Fig. 1).

Column 2 in Table 6 shows the composition of an albitized feldspar that occurs in the chloritized basalt immediately underlying the chert layer of the sulfide deposit. Albitization of igneous feldspars is a common feature of wall rock alteration associated with sulfide mineralization (Meyer and Hemley, 1968).

Column 3 of Table 6 shows an analysis of a spinel inclusion contained in a carbonate pseudomorph after euhedral olivine (Plate 5, Fig. 2). The spinel is almost certainly a remnant igneous mineral.

The last two analyses of Table 6 show the average compositions of feldspar and clinopyroxene remnants occurring in the gabbro of Core 88. Their compositions may be described as $\mathrm{An}_{62}$ and $\mathrm{En}_{50} \mathrm{Wo}_{44} \mathrm{Fs}_{6}$, respectively. Both minerals are almost completely replaced by chlorite in the rock.

The mineralogy of the Site 471 massive sulfide deposit is generally similar to that of ophiolite and recent mid-ocean ridge deposits, but differences do exist. The significance of these differences will be discussed in a subsequent report.

Table 4. Calcite compositions (wt. \%).

\begin{tabular}{lccccccc}
\hline & $\begin{array}{l}471-79-1, \\
49-54 \mathrm{~cm}\end{array}$ & $\begin{array}{c}471-79-1, \\
58-62 \mathrm{~cm}\end{array}$ & $\begin{array}{c}471-79-1, \\
74-77 \mathrm{~cm}\end{array}$ & $\begin{array}{c}471-79-1, \\
82-85 \mathrm{~cm}\end{array}$ & $\begin{array}{l}471-79-1, \\
93-97 \mathrm{~cm}\end{array}$ & $\begin{array}{c}471-79-1, \\
97-101 \mathrm{~cm}\end{array}$ & $\begin{array}{c}471-79-2, \\
0-5 \mathrm{~cm}\end{array}$ \\
\hline $\mathrm{SiO}_{2}$ & 0.00 & - & - & - & 0.00 & trace & 0.00 \\
$\mathrm{Al}_{2} \mathrm{O}_{3}$ & $0.17(3)^{\mathrm{a}}$ & - & - & - & $0.25(0)$ & $0.31(16)$ & $0.24(3)$ \\
$\mathrm{TiO}_{2}$ & trace & - & - & - & 0.00 & 0.00 & 0.00 \\
$\mathrm{FeO}^{*} \mathrm{~b}$ & 0.00 & $0.06(9)$ & 0.84 & 1.36 & 0.00 & $0.04(9)$ & $0.19(40)$ \\
$\mathrm{MgO}$ & $0.25(2)$ & trace & 0.00 & 0.00 & $0.09(1)$ & $0.53(34)$ & $0.37(38)$ \\
$\mathrm{CaO}$ & $50.61(48)$ & $50.79(196)$ & 53.21 & 50.62 & $53.66(45)$ & $52.86(146)$ & $53.62(186)$ \\
$\mathrm{Na} 2 \mathrm{O}$ & $0.01(1)$ & - & - & - & $0.02(1)$ & $0.03(4)$ & $0.03(2)$ \\
$\mathrm{K}_{2} \mathrm{O}$ & $0.01(1)$ & - & - & - & $0.01(0)$ & $0.02(2)$ & $0.01(1)$ \\
$\mathrm{MnO}$ & $9.80(30)$ & $9.60(94)$ & 8.47 & 6.87 & $5.28(38)$ & $3.49(74)$ & $3.30(91)$ \\
Total & $60.86(66)$ & $60.88(161)$ & 62.52 & 58.85 & 59.30 & $57.60(159)$ & $57.76(177)$ \\
No. Anals. & 5 & 5 & 1 & 1 & 2 & 4 & 9 \\
\hline
\end{tabular}

\footnotetext{
${ }^{a}$ Parenthesized figures represent the estimated standard deviation (esd) in terms of least units cited for the value to their immediate left, thus $0.17(3)$ indicates an esd of $0.03 \mathrm{wt} . \%$.

${ }^{b} \mathrm{FeO}^{*}=$ all iron calculated as $\mathrm{FeO}$.
} 
Table 5. Chlorite and biotite-phlogopite compositions (wt. \%).

\begin{tabular}{lcccc}
\hline & $\begin{array}{c}\text { Sample } \\
471-79-1, \\
97-101 \mathrm{~cm}\end{array}$ & $\begin{array}{c}\text { Sample } \\
471-79-2, \\
0-5 \mathrm{~cm}\end{array}$ & \multicolumn{2}{c}{$\begin{array}{c}\text { Sample } \\
471-88-1, \\
67-74 \mathrm{~cm}\end{array}$} \\
\hline & Chlorite & Chlorite & Chlorite & $\begin{array}{c}\text { Biotite- } \\
\text { phlogopite }\end{array}$ \\
\hline $\mathrm{SiO}_{2}$ & $30.62(110)^{\mathrm{a}}$ & $32.98(74)$ & $33.67(182)$ & $40.96(89)$ \\
$\mathrm{Al}_{2} \mathrm{O}_{3}$ & $15.85(49)$ & $10.73(144)$ & $11.04(14)$ & $12.17(56)$ \\
$\mathrm{TiO}_{2}$ & $1.36(83)$ & $0.15(26)$ & $0.19(1)$ & $2.31(24)$ \\
$\mathrm{FeO}^{* b}$ & $17.67(61)$ & $21.42(160)$ & $16.04(40)$ & $10.11(79)$ \\
$\mathrm{MgO}_{\mathrm{CaO}}$ & $20.08(45)$ & $20.54(183)$ & $27.30(90)$ & $20.93(34)$ \\
$\mathrm{Na}_{2} \mathrm{O}$ & $0.98(40)$ & $0.29(11)$ & $0.23(22)$ & $0.11(7)$ \\
$\mathrm{K}_{2} \mathrm{O}$ & $0.06(2)$ & $0.09(5)$ & $0.06(3)$ & $0.88(11)$ \\
$\mathrm{MnO}$ & $0.08(11)$ & $0.46(22)$ & 0.00 & $6.26(49)$ \\
$\mathrm{Total}$ & $0.49(3)$ & $0.61(10)$ & $0.31(4)$ & $0.16(5)$ \\
No. Anals. & $87.17(120)$ & $87.28(100)$ & $88.83(52)$ & $93.89(105)$ \\
\hline
\end{tabular}

a Parenthesized figures represent the estimated standard deviation (esd) in terms of least units cited for the value to their immediate left, thus 30.62 (110) indicates an esd of $1.10 \mathrm{wt} . \%$.

${ }^{b} \mathrm{FeO}^{*}=$ all iron calculated as $\mathrm{FeO}$.

\section{REFERENCES}

Bence, A. E., and Albee, A. L., 1968. Empirical correction factors for the electron microanalysis of silicates and oxides. J. Geol., 76: 382-403.

Finger, L. W., and Hadidiacos, C. G., 1972. Electron microprobe automation. Yearbook Carnegie Inst. Washington, 71:598-600.

Hekinian, R., Fevrier, M., Bischoff, J. L., et al., 1980. Sulfide deposits from the East Pacific Rise near $21^{\circ} \mathrm{N}$. Science, 207: 1433-1444.
Table 6. Compositions of miscellaneous minerals (wt.\%).

\begin{tabular}{|c|c|c|c|c|c|}
\hline & 1 & 2 & 3 & 4 & 5 \\
\hline $\mathrm{SiO}_{2}$ & - & $66.58(129)^{\mathrm{a}}$ & 0.17 & $51.84(59)$ & $51.51(69)$ \\
\hline $\mathrm{Al}_{2} \mathrm{O}_{3}$ & - & $18.75(67)$ & 25.62 & $29.23(44)$ & $2.44(85)$ \\
\hline $\mathrm{TiO}_{2}$ & - & 0.01 (1) & 1.36 & $0.07(2)$ & $0.60(10)$ \\
\hline $\mathrm{FeO}^{* \mathrm{~b}}$ & 0.00 & 0.00 & 22.14 & 0.00 & $6.03(87)$ \\
\hline $\mathrm{MgO}$ & 17.30 & 0.00 & 13.21 & $0.11(2)$ & $17.08(66)$ \\
\hline $\mathrm{CaO}$ & 32.37 & $0.40(57)$ & 1.17 & $12.00(143)$ & $20.70(80)$ \\
\hline $\mathrm{Na}_{2} \mathrm{O}$ & - & 11.10 (117) & 0.01 & $3.96(47)$ & 0.27 (3) \\
\hline $\mathrm{K}_{2} \mathrm{O}$ & - & $0.53(61)$ & 0.02 & $0.10(2)$ & trace \\
\hline $\mathrm{MnO}$ & 2.84 & $0.03(2)$ & 0.43 & $0.01(1)$ & $0.21(3)$ \\
\hline Total & 52.50 & $97.03(245)$ & 64.13 & 97.32 (125) & $98.82(86)$ \\
\hline No. Anals. & 1 & 2 & 1 & 5 & 4 \\
\hline
\end{tabular}

Note: 1. Sample 471-79-1, 82-85 cm; rhombohedral dolomite daughter crystal in recrystallized calcite gangue. 2. Sample 471-79-1, 93-97 cm; albitized feldspar in chloritized basalt. 3 . Sample 471-79-2, 0-5 cm; spinel inclusion in calcite pseudomorph after olivine in chloritized diabase; chromium was not determined. 4. Sample 471-88-1, 67-74 $\mathrm{cm}$; feldspar remnant in chloritized gabbro. 5. Sample 471-88-1, 67-74 $\mathrm{cm}$; clinopyroxene remnant in chloritized gabbro.

a Parenthesized figures represent the estimated standard deviation (esd) in terms of least units cited for the value to their immediate left, thus 66.58 (129) indicates an esd of $1.29 \mathrm{wt} . \%$.

${ }^{b} \mathrm{FeO}^{*}=$ all iron calculated as $\mathrm{FeO}$.

Humphris, S. E., and Thompson, G., 1978. Hydrothermal alteration of oceanic basalts by seawater. Geochim. Cosmochim. Acta, 42: $107-125$.

Meyer, C., and Hemley, J. J., 1968. Wall rock alteration. In Barnes, H. L. (Ed.), Geochemistry of Hydrothermal Ore Deposits: New York (Holt, Rinehart and Winston), pp. 175-176. 

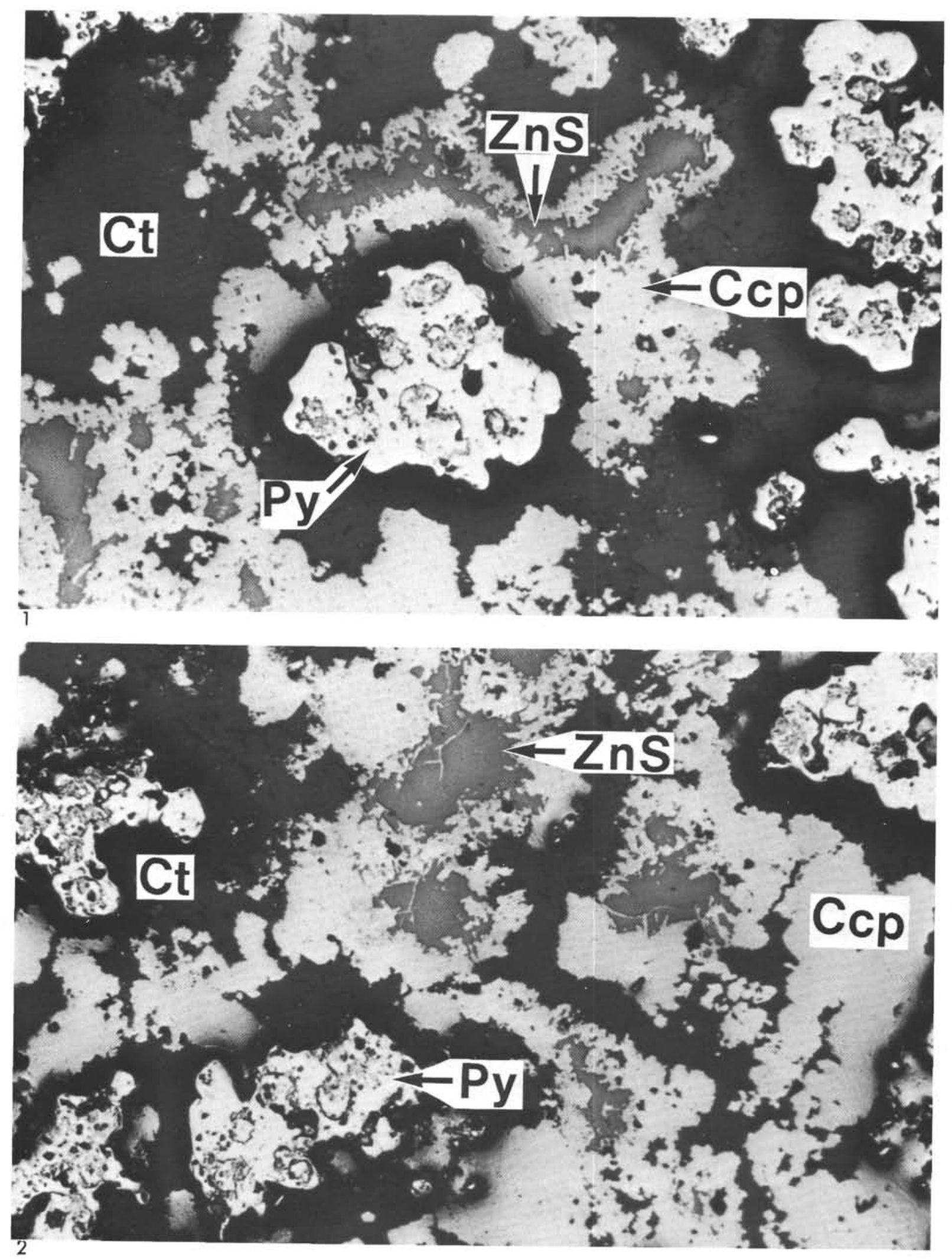

Plate 1. Figure dimensions for Plates 1-5 are $400 \times 600 \mu \mathrm{m}$ unless otherwise indicated. 1. Sample 471-79-1, 49-54 cm. (Pyrite, chalcopyrite, and $\mathrm{Zn}$-sulfide in calcite gangue; plane reflected light; $\mathrm{Py}=$ pyrite, $\mathrm{Ccp}=$ chalcopyrite, $\mathrm{ZnS}=\mathrm{Zn}$-sulfide, $\mathrm{Ct}=$ calcite.) 2 . Sample $471-79-1$, $49-54 \mathrm{~cm}$. Same as Fig. 1. 

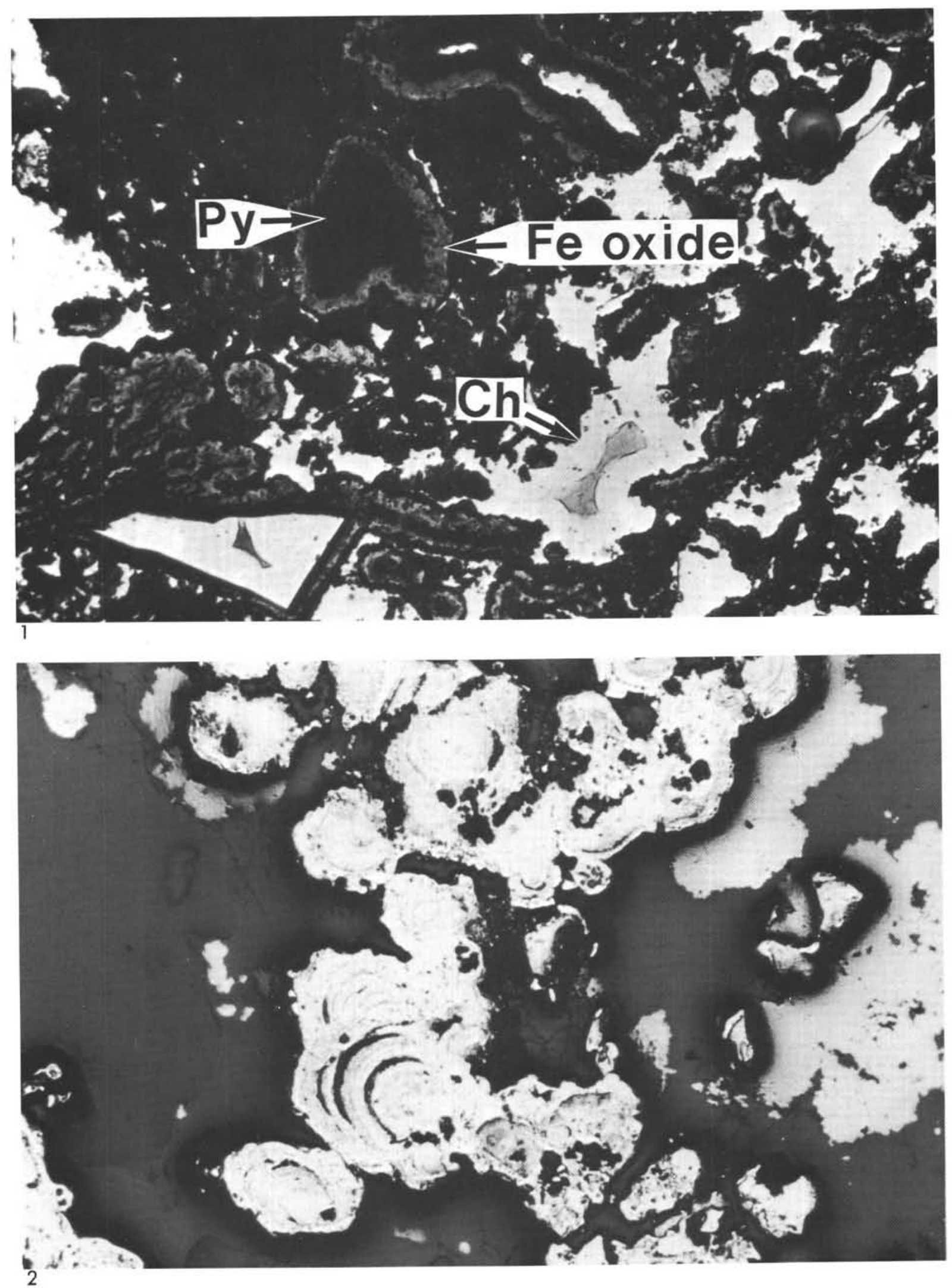

Plate 2. 1. Sample 471-79-1, 49-54 cm. (Partially oxidized pyrite in chert gangue from top of massive sulfide zone; plane transmitted light; Py = pyrite, $\mathrm{Ch}=$ chert.) 2 . Sample $471-79-1,49-54 \mathrm{~cm}$. (Framboidal pyrite in calcite gangue; plane reflected light.) 

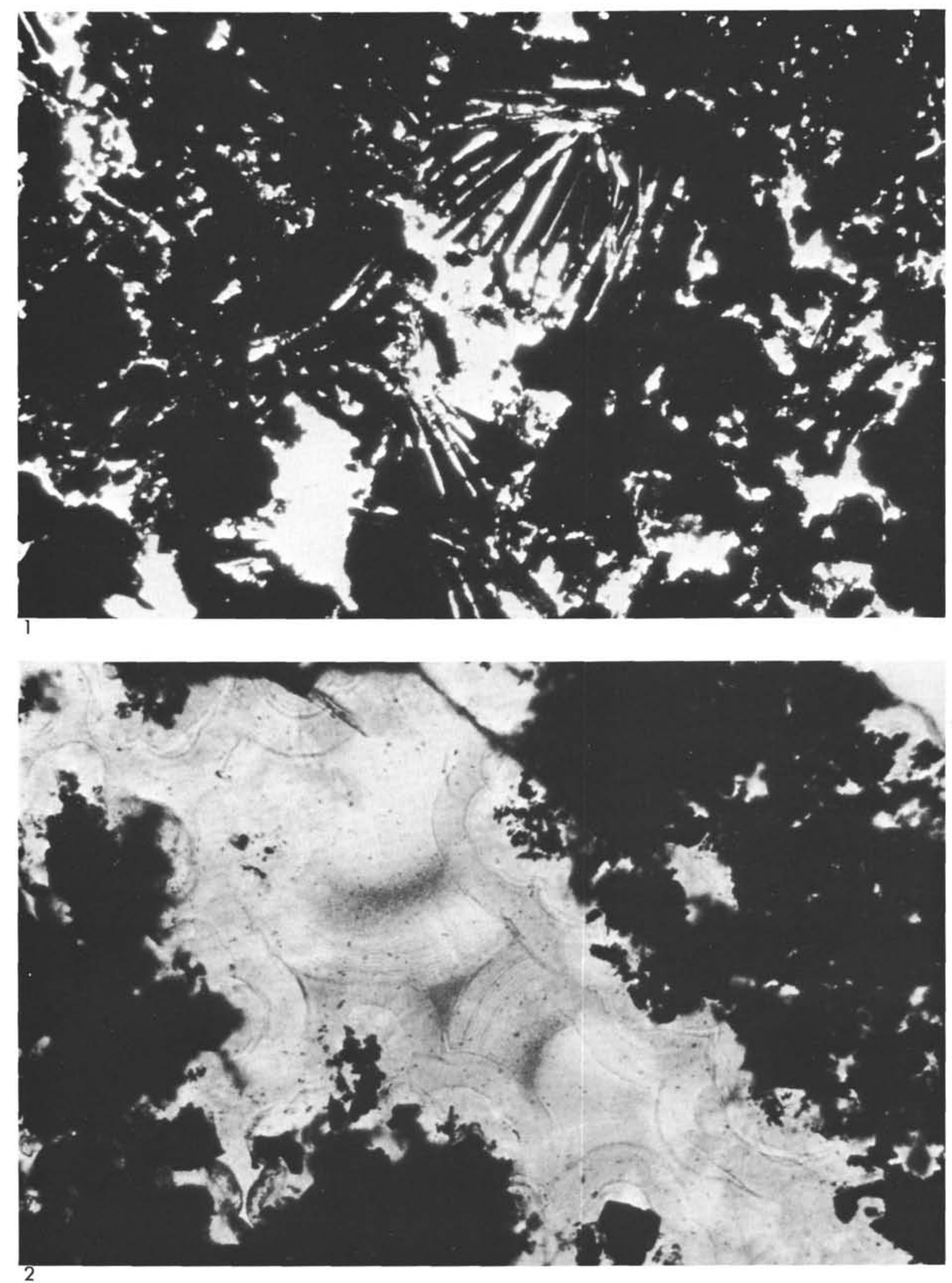

Plate 3. 1. Sample 471-79-1, 49-54 cm. (Pyrite in chert gangue similar in appearance to spherulitic marcasite clusters found at the " $21^{\circ} \mathrm{N}$ " area; plane transmitted light.) 2. Sample 471-79-1, 58-62 cm. (Spherulitic epitaxial overgrowths of chert gangue on sulfide grain surfaces; plane transmitted light; fig. dimensions are $250 \times 360 \mu \mathrm{m}$.) 

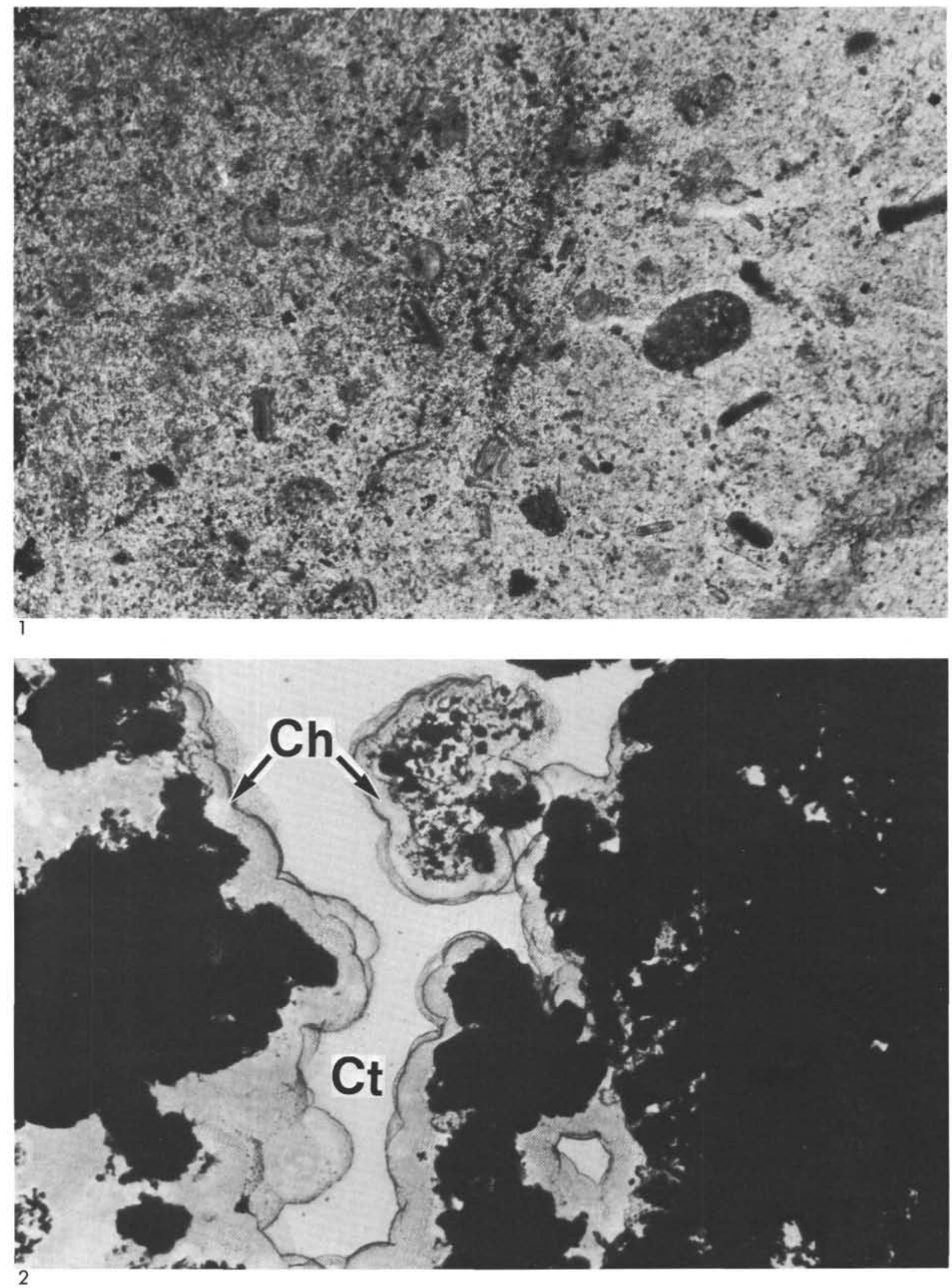

Plate 4. 1. Sample 471-79-1, 93-97 cm. (Chert clast containing silicified fossils that were probably coccoliths; plane transmitted light; Fig. dimensions are $250 \times 360 \mu \mathrm{m}$.) 2 . Sample 471-79-1, $82-85 \mathrm{~cm}$. (Calcite filling in voids lined by epitaxial chert; plane transmitted light; $\mathrm{Ch}=\mathrm{chert}, \mathrm{Ct}$ = calcite.) 

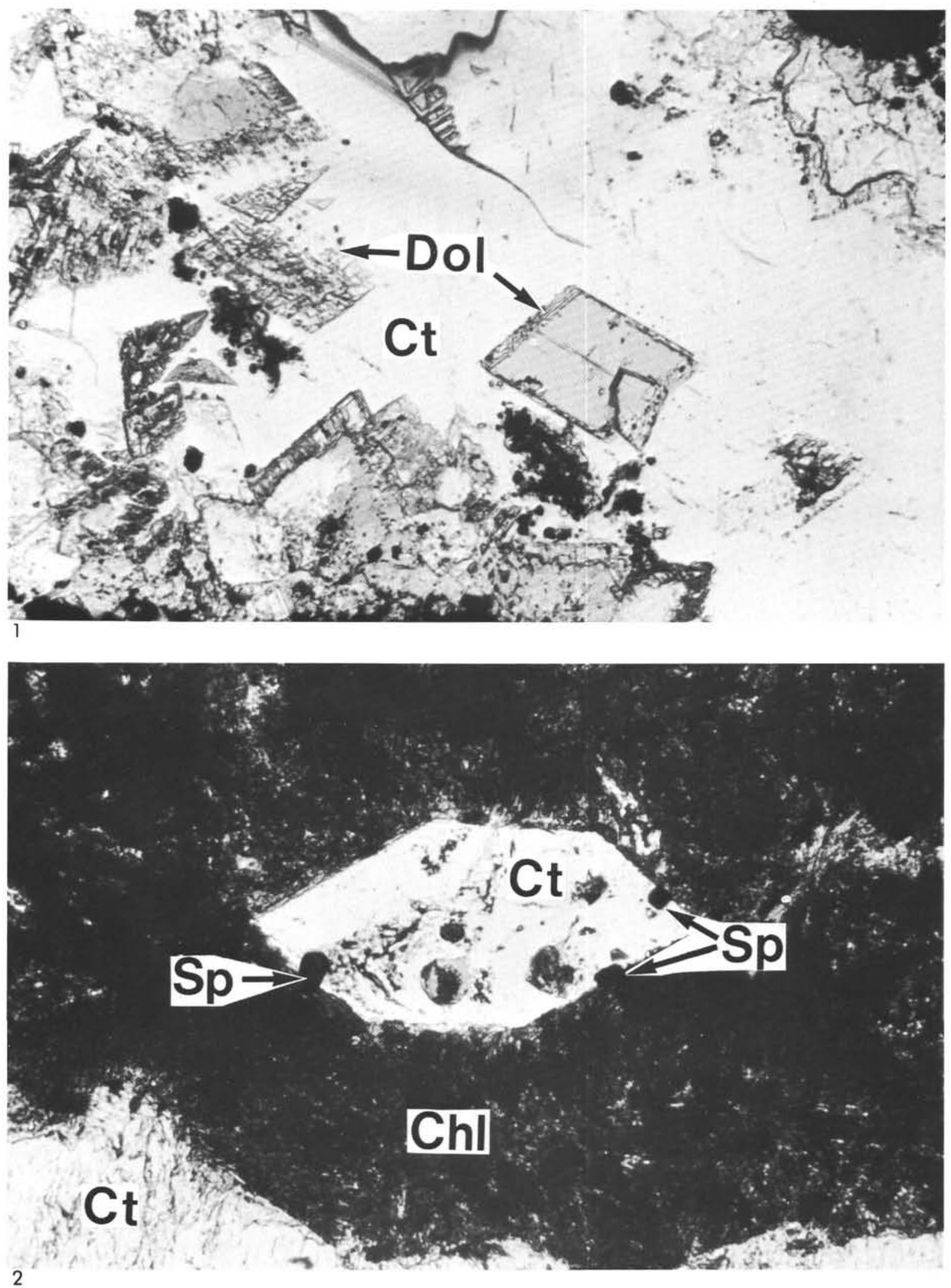

Plate 5. 1. Sample 471-79-1, 82-85 cm. (Dolomite daughter crystals growing in apparently recrystallized calcite gangue; plane transmitted light; $\mathrm{Dol}=$ dolomite, $\mathrm{Ct}=$ calcite; Fig. dimensions are $250 \times 360 \mu \mathrm{m}$.) 2. Sample 471-79-1, 97-101 cm. (Spinel-bearing calcite pseudomorph after euhedral olivine; plane transmitted light; $\mathrm{Ct}=$ calcite, $\mathrm{Sp}=$ spinel, $\mathrm{Chl}=$ chlorite.) 